\title{
Epidemio-clinical study of the first iterative cesarean in the gynecology- obstetric service at the teaching hospital of Cocody
}

\author{
Cassou R. Adjoby ${ }^{1 *}$, Soh V. Koffi ${ }^{1}$, Ibrahima S. Balde ${ }^{2}$, Denis Effoh ${ }^{1}$, Eleonore Gbary Lagaud ${ }^{1}$, \\ Aya V. Angoi ${ }^{3}$, Nawa M. Mamy ${ }^{2}$, Ngolo A. Soro', Zingbe Soumahoro ${ }^{1}$
}

\begin{abstract}
${ }^{1}$ Department of Gynecology and Obstetrics, Teaching Hospital of Angré/Abidjan, Cote d'Ivoire
${ }^{2}$ Department of Gynecology and Obstetrics, Ignace Deen Hospital, Conakry, Guinea

${ }^{3}$ Department of Gynecology and Obstetrics, Teaching Hospital of Cocody Abidjan, Cote d'Ivoire
\end{abstract}

Received: 13 April 2020

Accepted: 05 May 2020

\section{*Correspondence: \\ Dr. Cassou R. Adjoby, \\ E-mail: r.adjoby@yahoo.fr}

Copyright: (c) the author(s), publisher and licensee Medip Academy. This is an open-access article distributed under the terms of the Creative Commons Attribution Non-Commercial License, which permits unrestricted non-commercial use, distribution, and reproduction in any medium, provided the original work is properly cited.

\section{ABSTRACT}

Background: The iterative caesarean section, is a caesarean section that is performed on a uterus already healed, therefore for fear of maternal and perinatal risks, is recognized as one of the main causes of the inflation of caesarean section in the world. One in three caesarean sections is performed because of a scar uterus. Objective of this study was to analyse the epidemiological and clinical factors of iterative caesarean sections in the gynecology-obstetrics department at the Teaching Hospital of Cocody (Abidjan).

Methods: This was a retrospective and descriptive study conducted from June $1^{\text {st }}, 2018$ to May $31^{\text {st }}$, 2019, including 349 iterative caesarean section cases.

Results: The first iterative C-section accounted for $16.1 \%$ of the $\mathrm{C}$-section indications during the study period. The average age of the patients was 30 years. Nearly half of the patients practiced in the informal sector $47.9 \%$, were uneducated in $38.1 \%$ of cases and lived with a partner in $73.1 \%$ of cases. The majority of patients in this series $75.1 \%$ performed at least 4 ANCs. Patients were followed by prenatal visits in $61 \%$ of cases by midwives and in $8.6 \%$ of cases had an inter-reproductive space of less than 18 months. This study patients were evacuated in $46.4 \%$ of cases. Acute fetal distress was the first indication of first iterative caesarean section with $20.3 \%$ of cases. Emergency caesarean sections accounted for $84.4 \%$ of the cases in this series. Authors found maternal death $0.3 \%$ and $6.7 \%$ perinatal mortality.

Conclusions: The iterative caesarean section is a caesarean section likely to cause difficulties and complications peroperative. Although in constant improvement the prognosis of the mother-child couple still remains a problem in this context, prenatal monitoring should be the prerogative of obstetrician gynecologists.

Keywords: Cocody’s teaching hospital, Iterative caesarean section, Scar uterus

\section{INTRODUCTION}

According to Rivière, "Pregnancy and childbirth have from the beginning of time put the women at a fatal risk". "The introduction of caesarean section has enabled continuous improvement in the quality of obstetric care through the fight against maternal and perinatal mortality. ${ }^{2}$ Thus, the innovations made in surgical and anaesthetic techniques, to offer good maternal-fetal safety, have made caesarean section a common and safe intervention in obstetrics. It is in this context that authors are witnessing an increase in caesarean section practice across the globe with enough disparities. ${ }^{3-5}$ In Côte d'Ivoire, like the countries of sub-Saharan Africa, this rate is low, at $3.1 \% .^{6}$ One in three caesarean sections in the world is performed because of a scar uterus. ${ }^{7}$ The purpose 
of this work was to analyse the epidemiological and clinical factors of iterative first caesarean sections and to assess the materno-fetal prognosis.

\section{METHODS}

This was a cross-sectional, retrospective and descriptive study that focused on the iterative caesarean sections performed from June $1^{\text {st }}, 2018$ to May 31 ${ }^{\text {st }}, 2019$, a duration of twelve months in the gynecology and obstetrics department at the Teaching Hospital of Cocody. The study population consisted of all patients who received an iterative caesarean section (caesarean section performed on a uterus that had already undergone a first caesarean section) during the study period.

\section{Inclusion criteria}

- Iterative caesarean sections performed in the unit during this period of study regardless to pregnancy term and degree of urgency.

\section{Exclusion criteria}

- Caesarean sections performed for abnormalities of the pelvis.

The patients selected were those who underwent their first iterative caesarean section performed in the ward during the study period, regardless of the term of the pregnancy. Patients with a history of caesarean sections for pelvic abnormalities were not retained.

\section{Statistical analysis}

The data were analyzed statistically by the SPSS software.

\section{RESULTS}

\section{Patients frequency and epidemiological profile}

During the study period, 7,529 deliveries were performed, including 3,079 caesarean sections (40.9\%).

Table 1: Distribution of patients by age and parity.

\begin{tabular}{|llll|}
\hline \multirow{3}{*}{$\begin{array}{l}\text { Maternal age } \\
\text { (years) }\end{array}$} & Parameters & Number & Percentage \\
\cline { 2 - 4 } & $17-24$ & 48 & $13.7 \%$ \\
\hline \multirow{5}{*}{ Parity } & $25-39$ & 277 & $79.4 \%$ \\
\cline { 2 - 4 } & $\geq 40$ & 24 & $6.9 \%$ \\
\cline { 2 - 4 } & Pauciparous & 188 & $53.9 \%$ \\
\cline { 2 - 4 } & $\begin{array}{l}\text { Large } \\
\text { multiparous }\end{array}$ & 113 & $32.4 \%$ \\
\cline { 2 - 4 } & $\begin{array}{l}\text { Very large } \\
\text { multiparous }\end{array}$ & 6 & $12 \%$ \\
\hline
\end{tabular}

Iterative caesarean sections accounted for $16.1 \%$ of all caesarean sections. According to this study selection criteria, 349 caesarean sections performed on a unicicatrical uterus were selected.

Patient socio-demographic characteristics (maternal age and parity) are listed in Table 1.

The average age of the patients was 30 years with extremes 17-46 years. Paucipares were represented with $53.9 \%$ of cases.

Patients practised in the informal sector in $47.9 \%$ of cases and were illiterate in $38.1 \%$ of cases.

\section{Pregnancy monitoring}

The prenatal follow-up of patients in relation to the number of prenatal visits and the quality of the agent who performed the follow-up are recorded in Table 2.

Table 2: Distribution of patients by prenatal monitoring.

\begin{tabular}{|ll|ll|}
\hline \multirow{3}{*}{$\begin{array}{l}\text { Number of } \\
\text { ANCs }\end{array}$} & Parameters & Number & Percentage \\
\cline { 2 - 4 } & $0-1$ & 10 & $2.9 \%$ \\
\cline { 2 - 4 } & $2-3$ & 77 & $22 \%$ \\
\hline \multirow{2}{*}{$\begin{array}{l}\text { Quality of } \\
\text { the } \\
\text { consultant }\end{array}$} & Midwife & 262 & $75.1 \%$ \\
\cline { 2 - 4 } & Gynecologist & 123 & $61 \%$ \\
\cline { 2 - 4 } & GP & 9 & $35.2 \%$ \\
\cline { 2 - 4 } & Indetermined & 4 & $1.2 \%$ \\
\hline
\end{tabular}

Midwives performed prenatal follow-up in $61 \%$ of cases, despite the presence of a scar uterus, and in 4 patients the consultant did not identify himself in the mother-child notebook. Patients were evacuated in $46.4 \%$ of cases.

\section{Indications for caesarean section}

Table 3: Patient distribution by indication of first iterative caesarean section.

\begin{tabular}{|lll|}
\hline Indications & Number & Percentage \\
\hline Acute fetal distress & 71 & $20.3 \%$ \\
\hline Pre-eclampsia & 38 & $10.9 \%$ \\
\hline Uterus freshly scarred & 30 & $8.6 \%$ \\
\hline Cord circular & 29 & $8.3 \%$ \\
\hline $\begin{array}{l}\text { Pre-ruptured uterine } \\
\text { syndrome }\end{array}$ & 20 & $5.7 \%$ \\
\hline Fetal Macrosomia & 19 & $5.4 \%$ \\
\hline $\begin{array}{l}\text { Premature rupture of } \\
\text { membranes }\end{array}$ & 11 & $3.2 \%$ \\
\hline Others & 131 & $37.5 \%$ \\
\hline
\end{tabular}

The main reasons for caesarean section indications are shown in Table 3. 
Acute fetal pain was the main indication of caesarean section with $20.3 \%$ of cases, followed by preeclampsia with $10.9 \%$ of cases. Caesarean sections were divided into groups 4, 5, 7, 8, 9 and 10 of the Robson classification. The rate of prophylactic caesarean section performed in this series is $15.6 \%$.

\section{Maternal prognosis}

Authors studied the maternal prognosis through the perioperative and post-operative complications, these results are cumulated in Table 4.

Table 4: Maternal prognosis.

\begin{tabular}{|c|c|c|c|}
\hline Complications & & Number & Percentage \\
\hline \multirow{5}{*}{$\begin{array}{l}\text { Per-operative } \\
\text { complications }(n=20)\end{array}$} & Hemorrhage (difficulty with haemostasis) & 10 & $50 \%$ \\
\hline & Fetal extraction difficulty & 3 & $15 \%$ \\
\hline & Dehiscence of the scar & 1 & $5 \%$ \\
\hline & Multiple adhesions & 1 & $5 \%$ \\
\hline & Others & 5 & $25 \%$ \\
\hline \multirow{4}{*}{$\begin{array}{l}\text { Post-operative } \\
\text { complications }(n=35)\end{array}$} & Severe anemia & 12 & $34.1 \%$ \\
\hline & Sepsis & 2 & $5.8 \%$ \\
\hline & Parietal suppuration & 1 & $2.9 \%$ \\
\hline & Others & 20 & $57.2 \%$ \\
\hline
\end{tabular}

Surgical complications were dominated by haemostasis difficulties and post-operative anemia.

One maternal death was reported following an eclampsia attack.

\section{Fetal prognosis}

The new-borns had a good Apgar score in $72.6 \%$ of the cases $(n=263)$ and an observed perinatal mortality of $6.7 \%$.

\section{DISCUSSION}

\section{Frequency and epidemiological profile}

Authors recorded $16.1 \%$ of patients with iterative caesarean section out of a total of 3079 caesarean sections performed during the study period. The average age of patients in this study was 30 years. In Africa, Sima and Koulimaya-Gombet found an average of 29 years when Koffi found in the same service 26 years of average age. ${ }^{8-}$ 10 The largest number of this study patients, $47.9 \%$, worked in the informal sector. This study found that $56.2 \%$ of the iterative $1^{\text {st }} \mathrm{C}$-sections were performed in illiterate patients $(38.1 \%)$. Guihard showed, after a study on factors associated with caesarean section practice in France, that $64.7 \%$ of iterative caesarean sections were performed on patients with low levels of education. ${ }^{11}$ Pauciparous are the most numerous to be operated with a proportion of $53.9 \%$.

\section{Prenatal follow-up and admission}

Women with scar uterus were in $61 \%$ of cases followed by midwives compared to $35.2 \%$ of cases by gynecologists. This situation is abnormal reflecting a lack of medical referral by some midwives. The existence of a C-section history especially with a short interreproductive space is a hemorrhagic risk factor. This study patients were evacuated in $46.4 \%$ of the cases. Koulimaya-Gombet had $54.2 \%$ evacuees and Koffi, $70.9 \%$ of cases. In Africa, the presence of an unicicatricial uterus is a benchmark for a reference establishment in the context of a uterine test or prophylactic caesarean. ${ }^{1,9,10,12}$

\section{Caesarean section indication and degree of urgency}

It emerges from this study that acute fetal distress (AFD) with $20.3 \%$ of cases was the first indication of iterative cesarean section in this study series. Milos in his series in 2011, made an identical observation, with $10.16 \%$ of the cases. $^{13}$ The indications for AFD were not always justified and often abusive. The freshly scarred uterus $(8.6 \%)$ of the cases in this study constitutes an indication of elective cesarean section according to some authors when the inter-reproductive space is less than 18 months because a short interval seems to be a risk factor for rupture uterine due to incomplete scarring (fragility of the myometrium). ${ }^{14}$

Currently, there is no consensus on an ideal time frame for the elective cesarean between a cesarean and a subsequent pregnancy. However, a minimum period of 6 months would be ideal before a possible subsequent pregnancy if we stick to the conclusions of the work of Dicle et al. ${ }^{14}$ The prophylactic cesarean section rate performed in this series is $15.6 \%$. In the KoulimayaGombet series, $71.4 \%$ of cases had delivered by caesarean with a prophylactic caesarean section rate of $23.8 \%$. $^{9}$ In France, among women with scar uterus, a 
caesarean section is performed before labour in slightly more than half of the cases $(51 \%)$. In this study undermedicalized context, when the conditions for performing a uterine test are not met, only an iterative cesarean section can reduce maternal-fetal morbidity and mortality. ${ }^{12}$

\section{Materno-foetal prognosis}

The per-operative complications represented $5.7 \%$ of the cases in this study series. These complications are mostly hemorrhagic $65 \%$ (hemorrhage 30\%, labored hemostasis $20 \%$ and coagulopathy $15 \%$ ). This may be justified by the numerous adhesions caused by previous caesarean sections, which are frequently described in the black race. To avoid adhesions or reduce their incidence, it is advisable for the obstetrician to be rigorous and perform a correct abdominal toilet to reduce the accumulation of blood after any laparotomy. In case of adhesions, a corporeal hysterectomy could be used in front of a lower segment of difficult access or in front of a very adherent bladder.

The postoperative morbidity rate varies from one author to another (from $10 \%$ to $42 \%$ ) depending on whether or not they take into account the minor incidents which very often mark the aftermath of childbirth. ${ }^{15}$ Post-operative complications related to caesarean section during this study represented 35 cases, representing a morbidity rate of $10 \%$. This study rate is close to that found by Ouédraogo with $11.3 \%$ in Burkina-Faso. ${ }^{16}$ Maternal mortality linked to caesarean section has considerably reduced over the years thanks to various technical advances, antibiotic therapy and resuscitation. This mortality linked to cesarean sections may be secondary to: thromboembolic accidents, postpartum hemorrhages, puerperal infections, anesthetic accidents and amniotic embolism. ${ }^{17}$ In this study authors recorded a case of maternal death from eclampsia.

The new-borns had a good Apgar score in $72.6 \%$ of the cases $(n=263)$ and an observed perinatal mortality of $6.7 \%$. The specific consequences of cesarean section on neonatal adaptation of the fetus are now well known. There is an increase in transfers to the neonatal intensive care unit and respiratory distress in caesarean sections before labor, compared to deliveries by natural means. ${ }^{18,19}$ In fact, cesarean section delivery short-circuits both fetal stimulation (fetal stress with catecholamine production) and the phenomenon of chest compression during the passage of the pelvi-genital sector, which prevents the good absorption of pulmonary fluid from occur. ${ }^{20}$ Smith found that the risk of perinatal death related to the mode of delivery was 11 times higher in the uterine challenge group than in the elective cesarean section group. Authors reported $85 \%$ of deaths occurring after 39 weeks of gestation. This led him to conclude that when an elective cesarean section decision was made, it had to be completed before 40 weeks of gestation. ${ }^{21}$

\section{CONCLUSION}

The iterative caesarean section is a caesarean section likely to cause difficulties and complications peroperative. Although in constant improvement the prognosis of the mother-child couple still remains a problem in this study context, prenatal monitoring should be the prerogative of obstetrician gynaecologists. Awareness of pregnant women in consultation, as well as the health agents of peripheral maternity units is to be developed with the aim of reducing complications and avoiding missed opportunities for prophylactic iterative caesarean sections.

\section{Funding: No funding sources}

Conflict of interest: None declared

Ethical approval: The study was approved by the Institutional Ethics Committee

\section{REFERENCES}

1. Quenum G, Memadji M, Konan BR, Nigue L, Welffens-Ekra C. Césarienne de qualité: analyse des facteurs et des déterminants au CHU de Yopougon. Rev Int Sce Méd. 2001;2:109-15.

2. Dessolle L, Daraï E. Évolutions techniques de la césarienne EMC - Gynécologie-Obstétrique; Février. 2005;2(1):110-24.

3. Boerma T, Ronsmans C, Melesse DY, Barros AJ, Barros FC, Juan L, et al. Global epidemiology of use of and disparities in caesarean sections. The Lancet. 2018;392(10155):1341-8.

4. Orfali K. Beyond Numbers. The Multiple Cultural Meanings of Rising Cesarean Rates Worldwide. Am J Bioeth. 2012;12(7):54-6.

5. Blondel B. Kermarrec M. Enquête nationale périnatale 2010: les naissances en 2010 et leur évolution depuis 2003. Paris: inserm-Drees-DgS; 2011:132.

6. Boatin AA, Schlotheuber A, Betran AP, Moller AB, Barros AJ, Boerma $\mathrm{T}$, et al. Within country inequalities in caesarean section rates: observational study of 72 low- and middle-income countries. BMJ. 2018;360:k55.

7. Bretelle F, D'Ercole C, Cravelo L, Piehon L, Roger $\mathrm{V}$, Boubli L, et al. Accouchement sur utérus bicicatriciel: place de l'épreuve de cicatrice. J Gynecol Obstet Biol Reprod. 1988;27(4):421-5.

8. Sima B, Bang J, Obame R, Bibang F, Mewie A, Nzongue JP, et al. Utérus cicatriciel: aspect épidémiologiques et mode d'accouchement à la maternité du CHU d'Owendo (Gabon); Bull Med Owendo, Année. 2017;15 N43:45-51.

9. Koulimaya-Gombet CE, Diouf AA, Diallo M, Dia A, Sène C, Moreau JC, et al. Grossesse et accouchement des patientes ayant un antécédent de césarienne à Dakar: aspects épidémio-cliniques thérapeutiques et pronostiques. Pan African Med J. 2017;27(1):135.

10. Koffi A, Abauleth R, Bokassa E, Boni S, Bohoussou $\mathrm{K}$, Koné N. Les césariennes itératives au CHU de 
Cocody: Indications et pronostic foeto-maternel. Journal de la SAGO. 2004;5(1):36-9.

11. Guihard $\mathrm{P}$, Blondel $\mathrm{B}$. Les facteurs associés à la pratique d'une césarienne en France. Résultats de l'enquête nationale de 1995. J Gynecol Obstet Biol Reprod. 2001;30:444-543.

12. Kouakou P, Djanhan Y, Doumbia Y, Djanhan L, Ouattara M. Les ruptures utérines: aspects épidémiologiques et pronostic foeto-maternel à la maternité du CHU de Bouaké (Côte d'Ivoire). Revue CAMES. 2007;5:11-9.

13. Miloš V, Martina P, Martina B, Valérie T, Pravoslav S. Naissance après césarienne. Med Sci Monit. 2011;17(2):CR97-CR103.

14. Dicle O, Kucukler C, Pirnar T, Erata Y, Posaci C. Magnetic resonance imaging evaluation of incision healing after cesarean sections. Eur Radiol. 1997;7(1):31-4.

15. Broche DE, Courtois L, Maillet R, Riethmuller D. Césariennes encyclopédie médico-chirurgicale, Edit. Elsevier Masson; EM-consulte/Obstétrique. 2008:5102.

16. Ouédraogo C, Zoungrana T, Dao B, Dujardin B, Koné B. Quality cesarean at the yalgado ouédraogo hospital center in ouagadougou. Analysis of the determinants concerning 478 cases collected in the obstetrics and gynecology department. Med Afr Noire. 2001;48(11):443-51.

17. Deneux-Tharaux C, Carmona E, Bouvier-Colle MH, Breart G. Postpartum maternal mortality and cesarean delivery The American college of obstetricians and gynecologists. Obstet Gynecol. 2006;108(3):541-8.

18. Zongo A, Traoré M, Faye A, Gueye M, Fournier P, Dumont A. Effet de l'organisation des services de gynéco-obstétrique sur la mortalité maternelle hospitalière au Mali. Revue d'épidémiologie et de santé Publique. 2012;60(4):265-74.

19. Gerten KA, Coonrod DV, Bay RC, Chambliss LR. Cesarean delivery and respiratory distress syndrome: Does labor make a difference? Am J Obstet Gynecol. 2005;193:1061-4.

20. Le Ray C, Boithias C, Castaigne-Meary V, Foix l'Hélias L, Vial M, Frydman R. Caesarean before labour between 34 and 37 weeks: What are the risk factors of severe neonatal respiratory distress? Eur J Obstet Gynecol Reprod Biol. 2006;127:56-60.

21. Smith GCS, White IR, Pell JP, Dobbie R. Predicting caesarean section and uterine rupture among women attenmping vaginal birth after prior ceaseren section. Plos Med. 2005;2(9):e252.

Cite this article as: Adjoby CR, Koffi SV, Balde IS, Effoh D, Gbary Lagaud E, Angoi AV, et al.

Epidemio-clinical study of the first iterative cesarean in the gynecology-obstetric service at the teaching hospital of Cocody. Int J Reprod Contracept Obstet Gynecol 2020;9:2576-80. 